\title{
Organ fuel selection: brain
}

\author{
BY STEPHANIE A. AMIEL \\ UMDS, Guy's Hospital, London SE1 9RT
}

\section{Le sélection métabolique au niveau du cerveau}

\begin{abstract}
RÉSUMÉ
Le cerveau normalement doit obligatoirement consommer du glucose, mais il a le potentiel enzymatique pour métaboliser d'autres substrats. Une chute du glucose apporté au cerveau par sa circulation, comme dans l'hypoglycémie (faible concentration de glucose dans le sang), est suivie par une chute du taux métabolique cérébral en glucose, et par le déclenchement des réponses hormonales symptomatiques (qui agissent pour rétablir le glucose du sang), ainsi que par une perte de conscience. Le jeûne, qui augmente les corps cétoniques circulants, rend le sujet humain relativement résistant aux symptômes et à la perte de conscience de l'hypoglycémie. Owen et al. (1967) ont utilisé les mesures des corps cétoniques dans la circulation cérébrale pour montrer que le cerveau humain pourrait utiliser des corps cétoniques après un jeûne prolongé, mais la nécessité d'une période d'adaptation pour que le cerveau métabolise les corps cétoniques a été remise question dans des études sur l'animal dans lesquelles le cerveau du rongeur in vivo absorbait les corps cétoniques pendant le jeûne ou une perfusion de corps cétoniques à l'état nourri. La perfusion de corps cétoniques chez l'homme retarde l'apparition de ces réponses hormonales à l'hypoglycémie induite par l'insuline, réponses dont on pense qu'elles sont déclenchées dans le cerveau, ce qui laisse à penser que le cerveau de l'homme peut métaboliser les corps cétoniques s'ils sont apportés au cours de l'hypoglycémie aiguë. L'abaissement du niveau des corps cétoniques circulants au cours de l'hypoglycémie ne semble cependant pas augmenter le risque de dysfonction de la conscience. Le lactate est un autre substrat potentiel pour le métabolisme cérébral. Le cerveau du chien diabétique peut consommer du lactate pendant l'hypoglycémie. L'infusion de lactate chez l'homme retarde l'apparition des réponses hormonales et les altérations de la conscience dans l'hypoglycémie, ce qui laisse à penser que le cerveau de l'homme peut aussi utiliser le lactate pour maintenir le métabolisme et les fonctions dans l'hypoglycémie. D'autres substrats non glucidiques restent encore à tester. L'absorption d'acides aminés semble être sous le contrôle des concentrations relatives des acides aminés à chaîne ramifiée ou neutres dans le sang. Il semblerait que tandis que le cerveau utilise habituellement du glucose comme substrat énergétique pour son métabolisme et sa fonction, lorsque le glucose manque, il peut également utiliser des corps cétoniques et du lactate (et peut-être d'autres substrats).
\end{abstract}




\section{GLUCOSE}

Human brain tissue contains the enzymes necessary to metabolize a variety of substrates, and, in theory, has the biochemical capacity to metabolize glucose, ketones, lactate, fatty acids, glycerol and a variety of amino acids. Nevertheless, it has traditionally been considered that the brain uses glucose to fuel its metabolism and function, almost exclusively. Under normal circumstances this is largely true. In the resting, fasted state, the brain accounts for over $55 \%$ of the body's glucose consumption.

Over $90 \%$ of all the glucose taken up by cerebral tissue is oxidized to $\mathrm{CO}_{2}$ and water, the rest being metabolized through other means, either through the pentose phosphate pathway or through glycolysis to lactate and pyruvate. A negligible amount of glucose is stored in the brain so that the brain has virtually no glucose reserves. Thus, brain metabolism and brain function are dependent on a continued supply of exogenous glucose in its circulation and if blood glucose falls, so too will the rate of cerebral glucose metabolism.

Nagy et al. (1992) measured cerebral glucose consumption using an arterio-venousdifference technique in normal volunteers during controlled, insulin-induced hypoglycaemia. Cerebral glucose consumption fell when blood glucose concentration reached $3.6 \mathrm{mmol} / 1$, preceding the onset of symptomatic responses to hypoglycaemia or detectable cognitive dysfunction.

Under normal circumstances, cognitive dysfunction occurs relatively late during the development of hypoglycaemia and is rarely seen in healthy individuals. During controlled, insulin-induced hypoglycaemia in normal individuals, the first response to hypoglycaemia is stimulation of adrenaline secretion and of the sympathetic nervous system. This occurs at a plasma glucose concentration only a little below $4 \mathrm{mmol} / \mathrm{l}$ (Amiel, 1994). As the blood glucose fall progresses, an intensification of the autonomic response produces a symptom complex that an individual can learn to recognize as a warning that he or she should eat. Only if these initial defence mechanisms fail and plasma glucose falls below $3 \mathrm{mmol} / \mathrm{l}$ do we start to see evidence of cognitive dysfunction and a further decline in circulating plasma glucose is required to detect changes in the EEG (Amiel et al. 1991b). Current thinking is that most, if not all, of these responses are triggered by a fall in cerebral glucose metabolism (Biggers et al. 1989).

The rate-limiting step in cerebral cellular glucose metabolism is glucose transport into the cell. The expression of glucose transporters on cerebral cell surfaces is to some extent dictated by previous glycaemic experience. The ability of brain tissue to take up glucose increases after subacute hypoglycaemia (McCall et al. 1986), probably due to changing numbers of cerebral glucose transporters (Pardridge et al. 1990). However, it should be pointed out that other mechanisms, also, may be involved (Mooradian \& Morin, 1991).

Human subjects are better able to maintain rates of cerebral glucose during hypoglycaemia after a period of $56 \mathrm{~h}$ of moderate insulin-induced hypoglycaemia (Nagy et al. 1993), suggesting that the human brain is capable of responding to preceding hypoglycaemia with an up-regulation of cerebral glucose transporters and a better preservation of intracellular glucose levels and glucose metabolism during subsequent hypoglycaemia.

The glucose levels at which the hormonal and symptom responses to hypoglycaemia first begin are significantly lower in the tightly controlled hypoglycaemia-prone diabetic subject (Amiel et al. 1988). However, in the human clinical situation there is no adaptation of the glucose threshold for cognitive dysfunction as a result of the hypo- 
glycaemia in hypoglycaemia-experienced individuals (Maran et al. 1993). This suggests that there is differential adaptation of the efficiency of cerebral glucose extraction across the brain, with the brain centres responsible for counter-regulation being able to adapt to preceding hypoglycaemia, while the part of the brain responsible for higher function is not able to make such a protective alteration. This adaptation is a response to recurrent preceding hypoglycaemia rather than to the overall level of hypoglycaemic control and it is seen even in diabetic patients with a history of hypoglycaemia but in generally rather poor diabetes control and with high glycosylated haemoglobin (Cranston et al. 1994).

\section{KETONES}

Ketone bodies have long been the subject of interest as a potential fuel for cerebral metabolism because of early observations that subjects who had been fasting for prolonged periods of time had higher tolerance to induced hypoglycaemia (FourestFontecave et al. 1987). One of the metabolic changes that accompanies a prolonged fast is, of course, the elevation of circulating ketone bodies.

Owen et al. (1967) measured the arterio-venous difference across human brain in three obese subjects after a 6-week fast. They demonstrated that, at that stage, not only was the brain a net consumer of glucose but that it was also consuming the ketone bodies, $\beta$-hydroxybutyrate and acetoacetate. Drenick et al. (1972) later showed that during an insulin-tolerance test performed after prolonged fasting, again the brain became a net consumer of $\beta$-hydroxybutyrate. Coupled with the observation that cognitive function was better preserved and that there were fewer symptoms of hypoglycaemia in these fasted subjects, it was suggested that the human brain could start to metabolize ketone bodies and, thus, support metabolism and function, if it was given time for the adaptation to occur.

In experimental animals, the brain can consume ketones without any previous adaptation, if adequate concentrations of the ketones are available (Hawkins et al. 1971). Recently, it has been shown that human brain too may be able to metabolize ketones without previous adaptation. When normal volunteers were rendered hypoglycaemic in the presence or absence of an infusion of $\beta$-hydroxybutyrate, the counter-regulatory hormone response to the hypoglycaemia was markedly diminished and delayed. Cognitive function was not measured during this study but from the earlier data implicating the brain in the initiation of counter-regulatory hormone responses, these data are compatible with the suggestion that the human brain too can use ketones to maintain metabolism and function if they are available and if there is insufficient glucose for the purpose (Amiel et al. 1991a).

\section{LACTATE}

Under most circumstances of insulin-induced hypoglycaemia, ketones, also, will be low. Furthermore, abolishing hyperketonaemia during hypoglycaemia does not worsen cognitive dysfunction (Fanelli et al. 1993). However, other potential fuels for cerebral metabolism (including lactate) do become elevated as a result of counter-regulation to hypoglycaemia and they could theoretically be used by the brain to maintain function during hypoglycaemia.

Avogaro et al. (1990) examined the arterio-venous differences of several metabolic 
fuels in diabetic dogs during hypoglycaemia. They showed that the brain is a net consumer of glucose and a net producer of lactate. During hypoglycaemia the amount of glucose consumed by the brain fell. There was little effect on ketone bodies in this study but the brain became a net consumer of lactate, suggesting that during acute hypoglycaemia in insulin-dependent dogs, the brain can acutely utilize lactate (Avogaro et al. 1990); it is possible that this may occur also in the human brain.

McCall et al. (1986) examining brain substrate utilization in normal and chronically hypoglycaemic mice, showed an inverse relationship between the consumption of glucose and that of pyruvate and lactate by the brain. Mouse brain that had adapted to chronic preceding hypoglycaemia by increasing its ability to take up glucose from the surrounding medium showed a lesser dependence on other metabolic fuels, whereas the unadapted brain was easily able to take up pyruvate and lactate. To look at the possibility that the human brain might use lactate during acute hypoglycaemia to maintain its metabolism and function, we studied normal individuals and lowered their blood glucose in controlled steps using a hyperinsulinaemic-clamp technique, on two occasions, either with a simultaneous saline $(9 \mathrm{~g} \mathrm{NaCl} / \mathrm{l})$ infusion or an infusion of sodium lactate (Maran et al. 1994). Raising circulating lactate concentrations to the sorts of levels seen during moderate exercise markedly delayed and diminished the counterregulatory hormone responses.

\section{AMINO ACIDS}

To date only the large neutral amino acids have been studied in detail. The two families of these amino acids share a common transporter to enter brain tissue. The branchedchain amino acids such as leucine, isoleucine and valine, compete with tyrosine, phenylalanine and threonine. The rates of entry of the amino acids reflect the circulating concentrations and, in particular, the ratios between the various amino acids using the same transporter. In diabetic insulin-withdrawn animals, tyrosine levels are lower in the plasma and, therefore, also lower in the brain. In contrast, circulating levels of branched-chain amino acids, as represented by leucine, are very high in diabetes and, consequently, higher levels enter the brain (Crandell \& Fernstrom, 1983). Insulin treatment restores both plasma and brain levels of these amino acids to normal (Avogaro et al. 1990). Thus, brain uptake of such amino acids is dependent on their relative concentrations in the circulation.

\section{SUMMARY}

The brain's first choice for a metabolic fuel is glucose. In times of glucose lack, the brain can metabolize ketone bodies and lactate if they are available and by maintaining its metabolism, apparently, it also maintains its function. Brain metabolism of amino acid appears to be dictated by plasma levels, but the possibility that amino acids can support cerebral function during hypoglycaemia has not yet been investigated.

\section{REFERENCES}

Amiel, S. A. (1994). Hypoglycaemia without warning: a dangerous but reversible phenomenon. The Endocrinologist 4, 433-441.

Amiel, S. A., Archibald, H. R., Chusney, G. \& Gale, E. A. M. (1991a). Ketone lowers hormone responses to hypoglycaemia - evidence for acute cerebral utilization of a non-glucose fuel. Clinical Science 81, 189-194. 
Amiel, S. A., Pottinger, R. C., Archibald, H. R., Chusney, G., Cunnah, D. T. F., Prior, P. F. \& Gale, E. A. M. (1991b). Effect of antecedent glucose control on cerebral function during hypoglycemia. Diabetes Care 14, 109-118.

Amiel, S. A., Sherwin, R. S., Simonson, D. C. \& Tamborlane, W. V. (1988). Effect of intensive insulin therapy on glycemic thresholds for counterregulatory hormone release. Diabetes 37, 901-907.

Avogaro, A., Nosadini, R., Doria, A., Tremolada, C., Baccaglini, U., Ambrosio, F., Merkel, C., Nosadini, A., Trevisan, R. \& Fioretto, P. (1990). Substrate availability other than glucose in the brain during euglycemia and insulin-induced hypoglycemia in dogs. Metabolism 39, 46-50.

Biggers, D. W., Myers, S. R., Neal, D., Stinson, R., Cooper, N. B., Jaspan, J. B., Williams, P. E., Cherrington, A. D. \& Frizzell, R. T. (1989). Role of the brain in counterregulation of insulin induced hypoglycemia in dogs. Diabetes 38, 7-16.

Crandall, E. A. \& Fernstrom, J. D. (1983). Effect of experimental diabetes on the levels of aromatic and branched chain aminoacids in rat blood and brain. Diabetes 32, 222-230.

Cranston, I. A., Lomas, J., Maran, A., Macdonald, I, A. \& Amiel, S. A. (1994). Restoration of hypoglycaemia awareness in patients with a long history of hypoglycaemia without warning. Lancet 344, 283-287.

Drenick, E. J., Alvarez, L. C., Tamasi, G. C. \& Brickman, A. S. (1972). Resistance to symptomatic insulin reactions after fasting. Journal of Clinical Science 51, 2757-2762.

Fanelli, C., Di Vincenzo, A., Modarelli, F., Lepore, M., Ciofetta, M., Epifano, L., Pampanelli, S., Brunetti, P. \& Bolli, G. B. (1993). Post-hypoglycaemic hyperketonaemia does not contribute to brain metabolism during insulin-induced hypoglycaemia in humans. Diabetologia 36, 1191-1197.

Fourest-Fontecave, S., Adamson, U., Lins, P. E., Ekblomb, B., Sandahl, C. \& Strand, L. (1987). Mental alertness in response to hypoglycaemia in normal man: the effect of 12 hours and 72 hours fasting. Diabète et Métabolisme 13, 405-410.

Hawkins, R. A., Williamson, D. H. \& Krebs, H. A. (1971). Ketone body utilization by adult and suckling rat brain in vivo. Biochemical Journal 122, 13-18.

McCall, A. L., Fixman, L. B., Fleming, N., Tornheim, K., Chick, W. \& Ruderman, N. (1986). Chronic hypoglycemia increases brain glucose transport. American Journal of Physiology 251, E442-E447.

Maran, A., Cranston, I., Lomas, J., Macdonald, I. \& Amiel, S. A. (1994). Protection of lactate of cerebral function during hypoglycaemia. Lancet 343, 16-20.

Maran, A., Lomas, J., Macdonald, I. \& Amiel, S. A. (1993). Lack of protection of cerebral function in well controlled diabetic patients with hypoglycemia unawareness. Diabetes 42, Suppl. 1., 46.

Mooradian, M. D. \& Morin, A. M. (1991). Brain uptake of glucose in diabetes mellitus: the role of glucose transporters. American Journal of Medical Science 301, 173-177.

Nagy, R. J., O'Connor, A. \& Boyle, P. J. (1992). Modest hypoglycemia impairs brain glucose utilization before onset of symptoms. Diabetes 41, Suppl. 1,69A.

Nagy, R., O'Connor, A., Robinson, B. \& Boyle, P. J. (1993). Hypoglycemia unawareness results from adaptation of brain glucose metabolism. Diabetes 42, Suppl. 1, 133A.

Owen, O. E., Morgan, A. P., Kemp, H. G., Sullivan, J. M., Herrara, H. G. \& Cahill, G. F. (1967). Brain metabolism during fasting. Joumal of Clinical Investigation 46, 1589-1595.

Pardridge, W. M., Triguero, D. \& Farrell, C. R. (1990). Downregulation of blood-brain barrier glucose transporter in experimental diabetes. Diabetes 39, 1040-1044. 